\title{
The moderating role of socioeconomic status on motivation of adolescents' foreign language learning strategy use
}

\author{
Hye Won Shin ${ }^{a}$, Youngsoon So ${ }^{\text {b, * }}$ \\ ${ }^{a}$ Hankuk University of Foreign Studies, Seoul, Republic of Korea \\ b Department of English Language Education \& Center for Educational Research, Seoul National University, Seoul, Republic of Korea
}

\section{A R T I C L E I N F O}

\section{Article history:}

Received 21 January 2017

Received in revised form 25 November 2017

Accepted 27 November 2017

Available online 8 December 2017

\begin{abstract}
A B S T R A C T
Previous research has amply established the link between motivation and learning strategy with regards to language learning. However, there have been few investigations into the role of socioeconomic status (SES) in second or foreign language learning. Using questionnaire data on an 8th grade cohort $(N=203$, female $=110)$ from a large urban community in South Korea, we investigated SES as a moderator of the relationship between motivational orientation and language learning strategy use among adolescent students. A series of hierarchical linear models provided empirical evidence that, when drawing only on intrinsic motivation, low-SES adolescents tended to make relatively high use of social strategies. High-SES students, on the other hand, generally showed higher levels of effort, mastery goal orientation, and internal control, and they made greater use of cognitive, metacognitive, compensatory, and social strategies. These findings suggest that an adolescent's SES does affect the relationship between motivation and the use of various language learning strategies; they also suggest the need for greater fostering of low-SES students who are learning foreign languages.
\end{abstract}

() 2017 Elsevier Ltd. All rights reserved.

\section{Introduction}

A large body of literature has investigated the strategies used in successful second language learning, and various explanations for differences in strategy choice and use have been proposed (e.g., Chamot, 2008; Cohen, 1998, 2011; Griffiths, 2008b; Oxford, 2011). Among individual learner characteristics that could be related to strategy use, learner motivation is the one that has been investigated most (Pawlak, 2011). Another variable that may be associated with language learning strategy is socioeconomic status (SES). SES has been described as the social prestige among individuals or groups, typically indicated by parental income, parental education, and parental occupation. It is widely recognized that children born to parents of higher SES tend to benefit from a greater range of resources ${ }^{1}$ than children born to parents of lower SES (e.g., Bornstein \& Bradley, 2003); in particular, social class has been shown to be a major predictor of educational attainment (e.g., Kim \& Quinn, 2013; Sirin, 2005; White, 1982). Most research investigating this trend, however, has looked primarily at academic achievement among language minority ${ }^{2}$ learners where English is the dominant language (e.g., Sirin, 2005; White,

\footnotetext{
* Corresponding author.

E-mail address: youngsoon_so@snu.ac.kr (Y. So).

1 "Resources" can be taken to mean many things, including human, cultural, and social capital (Engberg \& Allen, 2011).

2 Language minority learners are language learners from underserved populations, typically of color and from lower SES backgrounds.
} 
1982). Few studies have addressed how socioeconomic background influences academic achievement when studying a foreign language (FL) (Butler \& Le, in press; Huang, Chang, Niu, \& Zhi, in press), and fewer studies have explored the influences of SES on the relationship between motivation and learning strategy. The present study seeks to fill this gap, by exploring how SES underlies motivational orientations in language learning strategy use.

\section{Literature review}

\subsection{Language learning strategies}

Language learning strategy centers on a learner's consciously chosen behaviors or actions for the purpose of improving and regulating his or her own language learning (Griffiths, 2008a, 2008b, 2013). When defining language learning strategies, some authors focus on the techniques or devices used to acquire knowledge (Rubin, 1981), while others highlight the behaviors or actions toward task (Oxford, 1990, 2011), or the role of consciousness (Cohen, 1998, 2011; Cohen \& Macaro, 2007). Second language (L2) researchers have not yet agreed on a comprehensive definition of "language learning strategy" (Dörnyei \& Skehan, 2003), but most distinguish between four types of strategy: (a) cognitive (i.e., specific to distinct learning activities), (b) metacognitive (i.e., knowing or reflecting about learning), (c) social/affective (i.e., involving interaction with others) (O'Malley, Chamot, Stewner-Manzanares, Kupper, \& Russo, 1985), and (d) compensatory (i.e., when encountering unfamiliar words or phrases) (Oxford, 1990).

Extensive research converges on the conclusion that strategy use plays an important role in language learning (e.g., Chamot, 2008; Cohen, 2011; Cohen \& Macaro, 2007; Griffiths, 2008a, 2008b). For example, Plonsky (2011) conducted a research synthesis of 61 primary studies, which revealed that the use of any learning strategy had a general positive effect on language learning $(d=0.49)$, as measured by skill-specific outcomes (e.g., reading, writing). Oxford's (1990) Strategy Inventory for Language Learning (SILL) is a self-report instrument that taps into a range of strategy choices and current understandings of language learning strategies. This instrument has provided researchers with encouraging psychometric features for assessing language learning strategies, with internal consistencies typically ranging between 0.93 and 0.98 (Oxford \& Burry-Stock, 1995). The present study incorporates items based on this SILL taxonomy.

\subsection{Motivational orientations}

According to Griffiths (2013), the effectiveness of a learning strategy would seem to depend on how appropriate it is for an individual student's circumstances, needs and goals. In other words, a learner's individual characteristics must be taken into account, and those characteristics include motivation.

Gardner (1985) posits that motivation can be conceptualized as having three dimensions: integrativeness, attitudes toward the learning situation, and motivations. Students who are motivated (1) monitor their own progress and therefore are able to reflect on their learning approaches (i.e., integrativeness), (2) view the learning task as interesting (i.e., attitudes), and (3) engage in behaviors that maximize learning (i.e., motivations). The present investigation utilizes this construct as the basis for measuring students' motivation to engage with course material and language learning. The instrument used to measure this construct is the Motivated Strategies for Learning Questionnaire (MSLQ; Pintrich, Smith, Garcia, \& McKeachie, 1991). It is a widely used instrument, consisting of 31 items and 50 statements, that captures three theoretical components of motivation: value beliefs, expectancy, and affect (Duncan \& McKeachie, 2005). In a meta-analytic search performed by Crede and Phillips (2011) involving 67 primary studies, the MSLQ subscales were meaningful predictors of academic performance. Following Booney, Cortina, Smith-Darden, and Fiori (2008), and the claim that it is valid and reliable (Crede \& Phillips, 2011), the present study employed this well-established instrument to assess motivational orientations in L2 learning.

\subsection{Strategy use and motivational orientation}

There is general agreement that extensive use of language learning strategies has a strong link with motivation (Booney et al., 2008; Cohen \& Dörnyei, 2002; Oxford \& Nyikos, 1989). This would seem unsurprising: more motivated learners are more likely to expend the effort required for strategy application. It is interesting to discover, however, that there is limited empirical evidence regarding the relationship between language learning strategies and motivation. Only two past studies have examined the issue with mixed target languages and populations. Both were undertaken in the Midwest region of the United States: Oxford and Nyikos's (1989) study consisted of undergraduates studying five different languages (French, Spanish, German, Russian, Italian) and majoring in a wide range of fields, and participants in the sample of Booney et al. (2008) were adolescents studying French, German, Latin, or Spanish as a foreign language. Both studies did find that highly motivated learners are likely to use a wide variety of strategies, thus increasing their chances of language learning success. The present study examines this issue by collecting data from adolescent learners of English as a foreign language in South Korea. 


\subsection{Socioeconomic status}

Terms such as social stratification, socioeconomic background, and socioeconomic status are used interchangeably to describe a person's material circumstances, level of formal schooling, and occupational status ${ }^{3}$ (Hauser, 1994; Mueller \& Parcel, 1981). Socioeconomic status has been a prominent element of educational research for the past several decades, and it has been found to be powerfully linked to academic achievement (Kim \& Quinn, 2013; Reardon, Valentino, Kalogrides, Shores, \& Greenberg, 2013; Sirin, 2005). Many researchers have found that children from low income families have fewer resources relevant to educational outcomes-parental involvement, for example (e.g., Engberg \& Wolniak, 2010). Moreover, teachers themselves have been shown to harbor lower expectations of less advantaged students (e.g., Tenenbaum \& Ruck, 2007; Timperley \& Phillips, 2003). Research examining the influence of social and economic differences on academic achievement, however, tends to focus on specific groups of minorities (e.g., Hispanics in the United States) (e.g., Reardon et al., 2013). Little attention has been given to SES, when assessing the success of students learning English as a foreign language (Butler, 2014). The present study aims to increase our understanding of the role of SES plays in L2 learning, in order to address the gaps in language learning strategy use between students from high-SES backgrounds and those from low-SES backgrounds, particularly in non-English speaking countries.

A proxy widely used by educational researchers in the United States to identify a student as being from a "lower-income household" is if he or she is eligible for a federally assisted free or reduced-price meal program at school. For the present study, which was conducted in South Korea, we could not use this metric-in 2014, the Seoul Metropolitan Office of Education implemented a universal meal program to feed every primary and middle school student in the capital (Choe, 2011). Instead, we categorized students as "high SES" or "low SES" depending on whether their families received assistance (i.e., subsidies or regular welfare payments) from the government. For example, a child in a family of three qualifies for a school fee subsidy if his family's monthly household income is equal to or less than KRW 1,820,487-approximately \$1500 (Ministry of Health and Welfare, 2017).

\section{Present study}

The main goal of the present study was to examine how SES affects the relationship between motivational orientations and strategy use in L2 English learning among adolescents. Specifically, two research questions were posed in the present study: Do low- and high-SES adolescent learners of English as a foreign language display different motivational orientations and language learning strategies? If so, to what extent does SES moderate the association between motivational orientations and language learning strategies?

\section{Methodology}

\subsection{Participants}

A sample of 203 Grade 8 students in eight classrooms from an urban public middle school participated in the study. Students had been studying English for approximately five years, as prescribed by the South Korean government at the time of this study. Among this sample of adolescents, 37 (18\%) were categorized as low-SES-that is, their families qualified for government subsidies. The students were all native speakers of Korean and nonnative speakers of English. There were more girls $(110,55 \%)$ than boys $(91,45 \%)$; two students did not indicate their gender.

\subsection{Measures}

Table 1 summarizes the psychometric properties of the subscales derived from the two measurement instruments: the Strategy Inventory for Language Learning (SILL) and the Motivated Strategies for Learning Questionnaire (MSLQ), adapted to the context of English as a foreign language. The reliability of scores for these subscales was evaluated using Cronbach's alpha. The coefficient alphas for the language learning strategies and motivational orientations scales were $0.89(k=12)$ and 0.93 $(k=24)$ respectively, with $0.95(k=36)$ for the composite scale. Items from the questionnaire were ordered randomly.

Language learning strategies. Strategy use was assessed using a four-subscale, 12-item measure adapted from the Strategy Inventory for Language Learning (SILL) (Oxford, 1990), in a similar fashion to Booney et al. (2008). Participants were asked to indicate how strongly they agree with the different types of language learning strategy (cognitive, metacognitive, compensatory, and social), answering questions on a five-point Likert-type scale ranging from 1 (never true of me) to 5 (always true of $m e$ ). The cognitive learning strategies subscale assessed students' rehearsal strategies for activation of information (e.g., "When I learn a new expression, I write it down repeatedly to practice it"). The metacognitive learning strategies subscale assessed students' critical evaluation (e.g., "I always try to notice the similarities and differences between Korean and English"). The compensatory strategies subscale assessed students' application of knowledge to new contexts (e.g., "When I cannot think of the correct expression to say or write, I find a different way to express the idea"). The social strategies subscale

\footnotetext{
${ }^{3}$ In this study, we use the same definition of SES as that describe by Hauser (1994), and Mueller and Parcel (1981).
} 
Table 1

Number of items per scale, item-to-total correlations, and Cronbach's alphas per item sets (N = 203).

\begin{tabular}{|c|c|c|c|c|}
\hline & & Items & $\leq \mathrm{r}_{\mathrm{it}} \leq$ & Cronbach's alpha \\
\hline \multirow[t]{5}{*}{ Learning Strategies } & Cognitive strategies & 3 & $0.67-0.75$ & 0.85 \\
\hline & Metacognitive strategies & 3 & $0.43-0.62$ & 0.72 \\
\hline & Compensatory strategies & 3 & $0.08-0.47$ & 0.49 \\
\hline & Social strategies & 3 & $0.46-0.62$ & 0.73 \\
\hline & Sum of subscales & 12 & $0.07-0.74$ & 0.89 \\
\hline \multirow[t]{9}{*}{ Motivation Orientations } & Integrative motivation & 3 & $0.37-0.59$ & 0.38 \\
\hline & Intrinsic motivation & 3 & $0.50-0.67$ & 0.69 \\
\hline & Self-efficacy & 3 & $0.68-0.73$ & 0.88 \\
\hline & Mastery orientation & 3 & $0.56-0.70$ & 0.69 \\
\hline & Performance orientation & 3 & $0.62-0.67$ & 0.78 \\
\hline & External regulation & 3 & $0.27-0.57$ & 0.74 \\
\hline & Internal control & 3 & $0.26-0.68$ & 0.63 \\
\hline & Effort & 3 & $0.57-0.71$ & 0.76 \\
\hline & Sum of subscales & 24 & $0.27-0.73$ & 0.93 \\
\hline
\end{tabular}

Note. $\mathrm{r}_{\mathrm{it}}=$ corrected item-total correlations.

assessed students' desire to work together with other students (e.g., "I work with other students to practice, review, or share information"). Analysis revealed a range of $0.07-0.75$ item-to-total correlations.

Motivational orientations. The Motivated Strategies for Learning Questionnaire (MSLQ) (Pintrich et al., 1991; Schmidt, Boraie, \& Kassabgy, 1996) is an eight-subscale, 24-item measure that asks participants to respond on a five-point scale, ranging from 1 (never true of me) to 5 (always true of me), about their goals and beliefs with regards to learning an L2. The eight subscales were designed to capture motivational orientations: integrative motivation (e.g., "Studying English is important because it will allow me to meet and converse with more people"), intrinsic motivation (e.g., "I think that what I am learning in this class is useful for me to know"), self-efficacy (e.g., "I expect to do well in this class"), mastery orientation (e.g., "Understanding my English coursework is important to me"), performance orientation (e.g., "Compared with others in this class, I think I'm a good student"), external regulation (e.g., "The main reason I am taking this class is because it is required for graduation"), internal control (e.g., "If I try hard enough, then I will understand the course material"), and effort (e.g., "I can honestly say that I made my best effort to learn English"). The item-to-total correlations ranged from 0.26 to 0.73 .

Socioeconomic status. Students were identified as low-SES if their families received assistance from the government. All other students were classified as high-SES.

\subsection{Data collection and analysis}

This study was conducted during normal classroom instruction. In a single group session under the guidance of their English subject teacher, participants completed a questionnaire that asked them about their motivation orientations and language learning strategies. Participation was voluntary, and students were not compensated financially for completing the questionnaire.

To examine whether SES moderated students' motivation to use learning strategies, we fit a series of multilevel models (also known as hierarchical linear models, or HLMs) with full maximum-likelihood estimation. HLM is necessary when the data has a nested structure. In this study, students are clustered within classes, and ordinary least-squares (OLS) models may lead to biased estimations (Raudenbush \& Bryk, 2002), which could in turn lead to misconstrued main effects. Although the intraclass correlation coefficients (ICCs)-which represent the extent to which classrooms accounted for student variability-were low, ${ }^{4}$ a multilevel modeling analysis was warranted because of the hierarchical data structure of students nested within classrooms. With individual-level covariates represented as Level 1, and class-level covariates as Level 2, HLM models were estimated separately for each language learning strategy using Stata, version 14 (StataCorp, 2015). These models were then used to identify the significant predictors and evaluate the variance in each outcome accounted for by the predictors.

\section{Results}

Table 2 shows the means, standard deviations, skewness, and kurtosis of the raw scores obtained on the adapted SILL and MSLQ scales. This table describes motivational orientations and language learning strategies combined and by SES groups. Table 3 shows the correlation matrices of the observed responses for motivation orientations and language learning strategies-significant positive correlations were observed among all variables.

Table 4 provides results of mean-level difference analysis, along with tests of statistical significance. As a group, the lowSES group had somewhat lower means than the high-SES group-the average score of the composite subscales was 3.13 $(S D=0.67)$. A $t$-test was conducted on the mean scores on each of the 12 subscales presented in the table. Results from the

\footnotetext{
${ }^{4}$ Computation of the ICCs yielded values less than 0.02 for all language learning strategy variables.
} 
Table 2

Means, standard deviations, skewness, and kurtosis for language learning strategies and motivation measures.

\begin{tabular}{|c|c|c|c|c|c|c|c|c|c|c|c|c|}
\hline & \multicolumn{4}{|c|}{$\begin{array}{l}\text { Total } \\
(N=203)\end{array}$} & \multicolumn{4}{|c|}{$\begin{array}{l}\text { Low SES } \\
(\mathrm{N}=37)\end{array}$} & \multicolumn{4}{|c|}{$\begin{array}{l}\text { High SES } \\
(\mathrm{N}=166)\end{array}$} \\
\hline & $M$ & $S D$ & skewness & kurtosis & $M$ & $S D$ & skewness & kurtosis & $M$ & $S D$ & skewness & kurtosis \\
\hline CLS & 2.84 & 1.00 & -0.01 & 2.53 & 2.50 & 1.15 & 0.32 & 2.27 & 2.91 & 0.95 & -0.03 & 2.65 \\
\hline MLS & 2.74 & 0.93 & -0.04 & 2.63 & 2.33 & 1.00 & 0.15 & 2.21 & 2.83 & 0.89 & -0.01 & 2.74 \\
\hline CS & 3.22 & 0.79 & -0.36 & 3.46 & 2.93 & 0.97 & -0.42 & 2.50 & 3.28 & 0.73 & -0.15 & 3.22 \\
\hline SS & 2.92 & 1.00 & -0.14 & 2.59 & 2.49 & 0.97 & -0.00 & 2.27 & 3.01 & 0.98 & -0.18 & 2.69 \\
\hline INTEM & 3.33 & 1.19 & 3.31 & 32.94 & 2.90 & 0.97 & -0.31 & 2.44 & 3.42 & 1.22 & 2.74 & 35.35 \\
\hline INTRM & 2.97 & 0.88 & -0.01 & 2.74 & 2.58 & 0.92 & 0.32 & 2.53 & 3.06 & 0.85 & -0.04 & 2.91 \\
\hline SE & 2.97 & 1.05 & -0.22 & 2.57 & 2.59 & 1.21 & 0.17 & 2.30 & 3.05 & 0.99 & -0.26 & 2.68 \\
\hline MO & 3.21 & 1.02 & 0.04 & 4.00 & 2.76 & 1.02 & -0.21 & 2.20 & 3.32 & 1.00 & 0.13 & 4.39 \\
\hline PO & 3.11 & 0.95 & -0.31 & 2.76 & 2.61 & 0.98 & -0.08 & 2.06 & 3.23 & 0.90 & -0.31 & 2.96 \\
\hline ER & 3.12 & 0.96 & -0.14 & 2.86 & 2.79 & 1.17 & -0.25 & 2.20 & 3.19 & 0.90 & 0.07 & 2.74 \\
\hline IC & 3.49 & 0.87 & -0.32 & 2.94 & 3.17 & 1.03 & -0.37 & 2.64 & 3.56 & 0.81 & -0.15 & 2.63 \\
\hline $\mathrm{EF}$ & 3.16 & 0.94 & -0.16 & 2.76 & 2.61 & 0.94 & 0.10 & 2.70 & 3.29 & 0.90 & -0.18 & 2.85 \\
\hline
\end{tabular}

Note. SD = standard deviation; CLS = cognitive learning strategies; MLS = metacognitive learning strategies; CS = compensatory strategies; SS = social strategies; INTEM = integrative motivation; INTRM = intrinsic motivation; SE = self-efficacy; MO = mastery orientation; PO = performance orientation; $\mathrm{ER}=$ external regulation; $\mathrm{IC}=$ internal control; $\mathrm{EF}=$ effort.

Table 3

Intercorrelations for observed variables of language learning strategies and motivations $(\mathrm{N}=203)$.

\begin{tabular}{|c|c|c|c|c|c|c|c|c|c|c|c|c|}
\hline & 1. & 2. & 3. & 4. & 5. & 6. & 7. & 8. & 9. & 10. & 11. & 12. \\
\hline 1. Cognitive learning strategies & 1.00 & & & & & & & & & & & \\
\hline 2. Metacognitive learning strategies & $0.68^{*}$ & 1.00 & & & & & & & & & & \\
\hline 3. Compensatory strategies & $0.50^{*}$ & $0.59^{*}$ & 1.00 & & & & & & & & & \\
\hline 4. Social strategies & $0.66^{*}$ & $0.69^{*}$ & $0.52^{*}$ & 1.00 & & & & & & & & \\
\hline 5. Integrative motivation & $0.40^{*}$ & $0.49^{*}$ & $0.40^{*}$ & $0.45^{*}$ & 1.00 & & & & & & & \\
\hline 6. Intrinsic motivation & $0.57^{*}$ & $0.64^{*}$ & $0.51^{*}$ & $0.64^{*}$ & $0.58^{*}$ & 1.00 & & & & & & \\
\hline 7. Self-efficacy & $0.69^{*}$ & $0.69^{*}$ & $0.57^{*}$ & $0.70^{*}$ & $0.45^{*}$ & $0.62^{*}$ & 1.00 & & & & & \\
\hline 8. Mastery orientation & $0.59^{*}$ & $0.65^{*}$ & $0.51^{*}$ & $0.63^{*}$ & $0.58^{*}$ & $0.72^{*}$ & $0.63^{*}$ & 1.00 & & & & \\
\hline 9. Performance orientation & $0.63^{*}$ & $0.68^{*}$ & $0.54^{*}$ & $0.66^{*}$ & $0.44^{*}$ & $0.60^{*}$ & $0.81^{*}$ & $0.67^{*}$ & 1.00 & & & \\
\hline 10. External regulation & $0.31^{*}$ & $0.37^{*}$ & $0.43^{*}$ & $0.38^{*}$ & $0.42 *$ & $0.38^{*}$ & $0.41^{*}$ & $0.44^{*}$ & $0.43^{*}$ & 1.00 & & \\
\hline 11. Internal control & $0.31^{*}$ & $0.37^{*}$ & $0.51^{*}$ & $0.32 *$ & $0.45^{*}$ & $0.50^{*}$ & $0.39^{*}$ & $0.51^{*}$ & $0.38^{*}$ & $0.42^{*}$ & 1.00 & \\
\hline 12. Effort & $0.65^{*}$ & $0.71^{*}$ & $0.57^{*}$ & $0.65^{*}$ & $0.49 *$ & $0.68^{*}$ & $0.74^{*}$ & $0.67^{*}$ & $0.71^{*}$ & $0.46^{*}$ & $0.50^{*}$ & 1.00 \\
\hline
\end{tabular}

Note. ${ }^{*} p<0.05$.

Table 4

Mean-level differences in language learning strategy and motivation $(\mathrm{N}=203)$.

\begin{tabular}{|c|c|c|c|}
\hline & $d f$ & $t$ & $p$ \\
\hline \multicolumn{4}{|l|}{ Language learning strategies } \\
\hline Cognitive learning strategies & 201 & 2.25 & 0.026 \\
\hline Metacognitive learning strategies & 201 & 3.00 & 0.003 \\
\hline Compensatory strategies & 201 & 2.50 & 0.013 \\
\hline Social strategies & 201 & 2.97 & 0.003 \\
\hline \multicolumn{4}{|l|}{ Motivation } \\
\hline Integrative motivation & 201 & 2.42 & 0.016 \\
\hline Intrinsic motivation & 201 & 3.11 & 0.002 \\
\hline Self-efficacy & 201 & 2.44 & 0.016 \\
\hline Mastery orientation & 201 & 3.06 & 0.003 \\
\hline Performance orientation & 201 & 3.68 & 0.000 \\
\hline External regulation & 201 & 2.29 & 0.023 \\
\hline Internal control & 201 & 2.50 & 0.013 \\
\hline Effort & 201 & 4.08 & 0.000 \\
\hline
\end{tabular}

analyses revealed that the low-SES students made less use of cognitive learning strategies $(t(201)=2.25, p=0.026)$, metacognitive learning strategies $(t(201)=3.00, p=0.003)$ and compensatory strategies $(t(201)=2.50, p=0.013)$, and were less likely to use social strategies $(t(201)=2.97, p=0.003)$ than high-SES students. Comparison of the self-reported motivational orientation indices for the two SES groups conformed to a similar pattern: integrative motivations, $t(201)=2.42, p=0.016$, intrinsic motivations, $t(201)=3.11, p=0.002$, self-efficacy, $t(201)=2.44, p=0.016$, mastery orientation, $t(201)=3.06$, $p=0.003$, performance orientation, $t(201)=3.68, p=0.000$, external regulation, $t(201)=2.29, p=0.023$, internal control, $t(201)=2.50, p=0.013$, and effort, $t(201)=4.08, p=0.000$. 
Table 5

Multilevel models for variables predicting EFL learning strategies among adolescent learners $(N=203)$.

\begin{tabular}{|c|c|c|c|c|}
\hline & $\begin{array}{l}\text { Cognitive } \\
\text { Model } 1\end{array}$ & Metacognitive Model 2 & $\begin{array}{l}\text { Compensatory } \\
\text { Model } 3\end{array}$ & $\begin{array}{l}\text { Social } \\
\text { Model } 4\end{array}$ \\
\hline \multicolumn{5}{|l|}{ Fixed effects } \\
\hline \multirow[t]{2}{*}{ Intercept } & $0.57^{*}$ & 0.27 & $1.02^{* * *}$ & 0.42 \\
\hline & $(2.07)$ & $(1.14)$ & $(4.26)$ & $(1.63)$ \\
\hline \multirow[t]{2}{*}{ Integrative motivation } & 0.01 & 0.08 & 0.01 & -0.00 \\
\hline & $(0.05)$ & $(0.04)$ & $(0.05)$ & $(0.05)$ \\
\hline \multirow[t]{2}{*}{ Intrinsic motivation } & $0.21^{*}$ & 0.16 & 0.15 & $0.39^{* * *}$ \\
\hline & $(1.01)$ & $(0.09)$ & $(0.09)$ & $(0.09)$ \\
\hline \multirow[t]{2}{*}{ Self-efficacy } & $0.35^{* * *}$ & $0.21^{*}$ & 0.09 & $0.34^{* * *}$ \\
\hline & $(0.10)$ & $(0.08)$ & $(0.09)$ & $(0.09)$ \\
\hline \multirow[t]{2}{*}{ Mastery orientation } & 0.14 & 0.06 & -0.02 & 0.15 \\
\hline & $(0.08)$ & $(0.07)$ & $(0.07)$ & $(0.08)$ \\
\hline \multirow[t]{2}{*}{ Performance orientation } & 0.06 & 0.11 & 0.10 & 0.05 \\
\hline & $(0.10)$ & $(0.09)$ & $(0.09)$ & $(0.09)$ \\
\hline \multirow[t]{2}{*}{ External regulation } & -0.01 & -0.01 & 0.10 & 0.06 \\
\hline & $(0.07)$ & $(0.06)$ & $(0.06)$ & $(0.06)$ \\
\hline \multirow[t]{2}{*}{ Internal control } & -0.13 & -0.06 & $0.19^{* *}$ & $-0.17^{*}$ \\
\hline & $(0.08)$ & $(0.07)$ & $(0.07)$ & $(0.07)$ \\
\hline \multirow[t]{2}{*}{ Effort } & 0.13 & $0.25^{* *}$ & 0.08 & 0.03 \\
\hline & $(0.10)$ & $(0.08)$ & (0.09) & (0.09) \\
\hline \multirow[t]{2}{*}{ SES } & -0.63 & -0.28 & -0.58 & -0.12 \\
\hline & $(0.52)$ & $(0.44)$ & $(0.45)$ & $(0.48)$ \\
\hline \multirow[t]{2}{*}{ Integrative motivation $\times \mathrm{SES}$} & -0.12 & -0.10 & -0.27 & 0.32 \\
\hline & $(0.22)$ & (0.19) & (0.19) & $(0.21)$ \\
\hline \multirow[t]{2}{*}{ Intrinsic motivation $\times$ SES } & -0.23 & -0.16 & -0.14 & $-0.59^{* *}$ \\
\hline & $(0.21)$ & $(0.18)$ & (0.19) & $(0.20)$ \\
\hline \multirow[t]{2}{*}{ Self-efficacy $\times$ SES } & -0.03 & -0.22 & 0.22 & -0.21 \\
\hline & (0.19) & $(0.16)$ & $(0.17)$ & $(0.18)$ \\
\hline \multirow[t]{2}{*}{ Mastery orientation $\times$ SES } & 0.09 & $0.60 * *$ & 0.07 & -0.04 \\
\hline & $(0.23)$ & $(0.20)$ & $(0.20)$ & $(0.22)$ \\
\hline \multirow[t]{2}{*}{ Performance orientation $\times$ SES } & 0.00 & 0.01 & 0.08 & 0.09 \\
\hline & $(0.27)$ & $(0.23)$ & $(0.23)$ & $(0.25)$ \\
\hline \multirow[t]{2}{*}{ External regulation $\times$ SES } & -0.16 & -0.03 & -0.20 & -0.08 \\
\hline & $(0.16)$ & $(0.14)$ & $(0.14)$ & $(0.15)$ \\
\hline \multirow[t]{2}{*}{ Internal control $\times \mathrm{SES}$} & 0.22 & -0.09 & $0.37^{*}$ & 0.03 \\
\hline & $(0.19)$ & $(0.17)$ & $(0.17)$ & $(0.18)$ \\
\hline \multirow[t]{2}{*}{ Effort $\times$ SES } & $0.44^{*}$ & 0.07 & 0.04 & $0.45^{*}$ \\
\hline & $(0.22)$ & $(0.18)$ & $(0.19)$ & $(0.20)$ \\
\hline \multicolumn{5}{|l|}{ Random effects } \\
\hline SD (cons) & $0.0801859(0.0744101)$ & $1.35 e-13(1.23 e-12)$ & $\begin{array}{l}0.0589576 \\
(0.0754379)\end{array}$ & $0.0773459(0.0720689)$ \\
\hline SD (residual) & $0.6490974(0.0329011)$ & $0.5546451(0.0275267)$ & $\begin{array}{l}0.5650544 \\
(0.0287234)\end{array}$ & $0.6093963(0.0309464)$ \\
\hline \multicolumn{5}{|l|}{ Goodness-of-fit statistics } \\
\hline -2log likelihood & 403.245 & 336.7818 & 346.2818 & 377.744 \\
\hline AIC & 443.245 & 376.7818 & 386.2818 & 417.744 \\
\hline BIC & 509.5092 & 443.0459 & 452.546 & 484.0081 \\
\hline
\end{tabular}

Note. ${ }^{*} p<0.05 ;{ }^{* *} p<0.01 ;{ }^{* * *} p<0.001$.

Standard errors of parameter estimates are denoted in parentheses. $-2 L L=-2 \log$ likelihood; AIC $=$ Akaike information criterion; BIC $=$ Bayesian information criterion.

Table 5 presents coefficients and standard errors obtained from the HLM analyses for each of the strategy dependent variables. In the first model, cognitive strategies were positively related to intrinsic motivation, $\beta=0.21, p<0.05$, and selfefficacy, $\beta=0.35, p<0.001$. There was interaction between effort and SES, $\beta=0.44, p<0.05$, in terms of students' reported use of cognitive strategies, showing that high-SES students displayed higher effort than low-SES ones. In Model 2, students' effort, $\beta=0.25, p<0.01$, was the strongest predictor of their reported metacognitive strategy use, followed by self-efficacy, $\beta=0.21, p<0.05$. An interaction was detected between mastery orientation and SES, which was significant for metacognitive strategies, with low-SES students reporting significantly less use of metacognitive strategies than their high-SES counterparts, $\beta=0.60, p<0.01$. In Model 3, student reports of compensatory strategies are significantly and positively associated with internal control $(\beta=0.19, p<0.01)$. Furthermore, for compensatory strategies, internal control significantly interacted with SES, $\beta=0.37, p<0.05$, showing that when they rely on internal control, the students from higher SES backgrounds employed more compensatory strategies than their low-SES counterparts. The final model shows that intrinsic motivation $(\beta=0.39$, $p<0.001)$ and self-efficacy $(\beta=0.34, p<0.001)$ are significant and positively related to social strategies, while students' internal control $(\beta=-0.17, p<0.01)$ was negatively related to the social strategy variable. We also find a statistically significant and positive interaction emerged between effort and SES on social strategies $(\beta=0.45, p<0.05)$. Interestingly, there 
was a significantly negative interaction between intrinsic motivation and SES for social strategies, $\beta=-0.59, p<0.01$, revealing that low-SES students displayed higher intrinsic motivation than high-SES ones, when other variables were controlled for.

\section{Discussion and conclusions}

The overarching purpose of this study was to generate insights about the role of SES in L2 learning. Specifically, it explored the extent to which SES may influence the relationship between motivation and language learning strategies. As a first step, ttests were performed and the results revealed that there were extensive differences between low- and high-SES adolescents, with the latter surpassing the former in every language learning strategy subscale. In other words, the high-SES adolescent L2 learners appeared to use a variety of strategies to a much greater extent than the low-SES adolescent L2 learners.

Given these differences, we then conducted a series of HLM models that can accommodate the nested data structure in order to better understand the relationship between motivations and language learning strategies. We found that the adolescent learners participating in this study reported wider usages of language learning methods, and, when drawing on either intrinsic motivation or self-efficacy, they employed three of the four foreign language learning strategy types. In fact, variability (and frequency) in strategy use is a factor related to success in language learning (e.g., Green \& Oxford, 1995; Griffiths, 2008a). This provides additional evidence to support the idea, already demonstrated by other researchers (e.g., Booney et al., 2008), that motivation plays a facilitative role in language learning strategy use. However, this study does not corroborate with the specific findings of Booney et al. (2008) which found that students' integrative motivation (and not intrinsic motivation) had the highest predictive power of L2 learning strategies. This difference is to a certain extent surprising, because both studies used a target population of adolescent L2 learners. However, the present study was composed of a homogenous sample of Korean learners studying English as a foreign language, while Booney et al. examined learners from various first language (L1) backgrounds, proficiency, and target languages. It is conceivable that L1 background, L2 proficiency, and sociocultural environments also affect strategy selection. Griffiths (2003), for example, found that Europeans with high proficiency in a foreign language chose strategies relating to reading more frequently than Asians proficient in a foreign language.

The importance of SES group differences lies in the fact that motivational orientation is a strong predictor of language learning strategy use. Notably, economically advantaged learners generally showed higher levels of effort, mastery goal orientation, internal control, and self-efficacy, and they made greater use of cognitive strategies, metacognitive strategies, compensatory strategies, and social strategies. This was anticipated, and our results were in line with other educational research studies (e.g., Bornstein \& Bradley, 2003; Hoff, 2006; Kim \& Quinn, 2013; Sirin, 2005). Unique to this study's data is the finding that high-SES students did not think social strategies were as useful as their less advantaged counterparts, as evidenced by the Model 4 results of the HML analyses (Table 5). Given that social strategies are related to tendencies to interact with others (see Items \#5, 11, and 36 in Appendix A), when other factors are controlled for, low-SES learners tend to be more willing to practice with others to improve their L2 proficiency than their high-SES peers. One possible explanation is that high-SES learners may have more resources available to assist their L2 learning, ${ }^{5}$ and therefore feel less need to share information with friends.

Taken together, these results indicate something that has not been previously documented in the empirical applied linguistics literature: substantial differences in strategy use between L2 learners of different socioeconomic status. This study suggests there is a pressing need for English language teachers to encourage all students to use strategies that drive learning. In so doing, however, they should tailor their teaching methods to the socioeconomic backgrounds of their students. For lowSES students, teachers may want to emphasize cognitive, metacognitive, and compensatory strategy approaches. For high-SES students, in contrast, the teachers may want to modify instruction to encourage more peer-to-peer interaction in the (language learning) classroom, whether through group work or team projects.

While raising questions for future research, this study has certain limitations that must be considered carefully. First, while the sample might be viewed as representative of 8th grade EFL learners in an urban community in South Korea, the relatively small number of low-SES students may limit the generalizability of the study. Future studies should include larger sample sizes in varying contexts and grade levels. Second, the study is reliant on student self-reporting, which can be vulnerable to self-serving responses, as reported by Stoeber and Hotham (2013). Third, the internal consistency of three subscales (compensatory strategies, integrative motivation, internal control) had reliability estimates slightly below Nunnally and Bernstein's (1994) criterion of 0.70 (see Table 1), which could be because not a many number of items were included in each subscale (Cortina, 1993). In future studies, researchers may want to include more items tapping these subscales, to increase internal consistency of each subscale and enhance the ability to draw more meaningful conclusions from the results. Finally, South Korea is just one of many non-English speaking countries, and the big challenge will be accumulating research from other countries, especially from developing countries, that will further explore how SES influences language learning strategy use, and where gaps exist between people of different SES.

\footnotetext{
${ }^{5}$ High-SES learners can afford to attend private language institutes or work with tutors. Highly competitive language institutes, for instance, often employ nonsocial strategies that prioritize individual advancement.
} 
Despite these limitations, the present study provides evidence that an EFL learner's socioeconomic background differentially affects language learning strategy use when associated with motivational orientations. Our findings suggest that the benefits of language learning strategy use are stronger for socioeconomically advantaged adolescents than for their less advantaged peers, who often show little motivation to learn. We hope this study raises awareness about the gap between low- and high-SES language learners among foreign language teachers and researchers, and shows the need for an increased focus on improving language learning strategy use among socioeconomically disadvantaged students in secondary schools.

\section{Appendix A}

\section{Questionnaire}

1. I try to find the meaning of an English word by breaking down the word into parts that I understand.

2. When I read, I do not look up every unfamiliar word.

3. When I learn a new expression, I write it down repeatedly to practice it.

4. Learning English is a hobby for me.

5. I work with other students to practice, review, or share information.

6. Understanding my English coursework is important to me.

7. I want to get better grades in this class than most other students.

8. I'm confident I can do an excellent job on the assignments and tests in this course.

9. When I learn a new word in English, I try to relate it to other English words I know.

10. If I do not understand someone speaking, I ask that person to slow down or repeat.

11. When studying for this class, I often explain the material to a classmate or a friend.

12. If I don't understand the course material, it is because I'm not trying hard enough.

13. Studying English will help me to broaden my network of friends.

14. The main reason I am taking this class is because it is required for graduation.

15. I prefer class work that really challenges me.

16. I like what I am learning in this class.

17. Studying English will allow me to travel and interact with diverse groups of people.

18. When I learn a new expression, I say it repeatedly to practice it.

19. Even when I don't like a class, I work hard to get a good grade.

20. I am taking this class because I want to get into a good college.

21. I make good use of my study time for this course.

22. It is my own fault if I don't learn the material in this course.

23. I can honestly say that I made my best effort to learn English.

24. Compared with others in this class, I think I'm a good student.

25. Even when assignments are dull or boring, I keep working until I finish them.

26. I'm certain I can master the skills being taught in this class.

27. When I learn a new expression, I read it repeatedly to practice it.

28. If I try hard enough, I will understand the course material.

29. I think that what I am learning in this class is useful for me to know.

30. I always try to notice the similarities and differences between Korean and English.

31. I often choose assignments that I can learn something from, even if they require more work.

32. My study skills are excellent compared with others in this class.

33. I expect to do well in this class.

34. When I cannot think of the perfect expression, I find a different way to express the idea.

35. I am taking this class because I want a good job after graduation.

36. Studying English is important because it will allow me to meet and converse with more people.

\section{References}

Booney, C. R., Cortina, K. S., Smith-Darden, J. P., \& Fiori, K. L. (2008). Understanding strategies in foreign language learning: Are integrative and intrinsic motives distinct predictors? Learning and Individual Differences, 18, 1-10.

Bornstein, M. C., \& Bradley, R. H. (Eds.). (2003). Socioeconomic status, parenting, and child development. Mahwah, NJ: Lawrence Erlbaum.

Butler, Y. G. (2014). Parental factors and early English education as a foreign language: A case study in Mainland China. Research Papers in Education, 29(4), $410-437$.

Butler, Y. G., \& Le, V.-N. (in press). A longitudinal investigation of parental social-economic status (SES) and young students' learning of English as a foreign language. System, https://doi.org/10.1016/j.system.2017.07.005.

Chamot, A. (2008). Strategy instruction and good language learners. In C. Griffiths (Ed.), Lessons from good language learners (pp. 266-281). Cambridge, UK: Cambridge University Press.

Choe, S.-H. (2011, August 24). In first, South Korea votes on social policy. The New York Times. Retrieved from http://www.nytimes.com/2011/08/25/world/ asia/25korea.html.

Cohen, A. (1998). Strategies in learning and using a second language. London and New York: Longman.

Cohen, A. (2011). Strategies in learning and using a second language (2nd ed.). Harlow, UK: Longman. 
Cohen, A., \& Dörnyei, Z. (2002). Focus on the language learner: Motivation, styles and strategies. In N. Schmitt (Ed.), An introduction to applied linguistics (pp. 170-190). London, UK: Edward Arnold.

Cohen, A., \& Macaro, E. (2007). Learner strategies, Oxford, UK: Oxford University Press.

Cortina, J. M. (1993). What is coefficient alpha? An examination of theory and applications. Journal of Applied Psychology, 78(1), 98-104.

Crede, M., \& Phillips, A. (2011). A meta-analytic review of the motivated strategies for learning questionnaire. Learning and Individual Differences, 21(4), $337-346$.

Duncan, T. G., \& McKeachie, W. J. (2005). The making of the motivated strategies for learning questionnaire. Educational Psychologist, 40(2), 117-128.

Dörnyei, Z., \& Skehan, P. (2003). Individual differences in second language learning. In C. Doughty, \& M. Long (Eds.), Handbook of second language acquisition (pp. 589-630). Oxford, UK: Blackwell.

Engberg, M. E., \& Allen, D. J. (2011). Uncontrolled destinies: Improving opportunity for low-income students in American higher education. Research in Higher Education, 52(8), 786-807.

Engberg, M. E., \& Wolniak, G. C. (2010). Examining the effects of high school contexts on postsecondary enrollment. Research in Higher Education, 51(2), $132-153$.

Gardner, R. C. (1985). Social psychology and second language learning: The role of attitudes and motivation. London, UK: Edward Arnold.

Green, J., \& Oxford, R. L. (1995). A closer look at learning strategies, L2 proficiency, and gender. TESOL Quarterly, $29(2), 261-297$.

Griffiths, C. (2003). Patterns of language learning strategy use. System, 31, 367-383.

Griffiths, C. (2008a). Lessons from good language learners. Cambridge, UK: Cambridge University Press.

Griffiths, C. (2008b). Strategies and good language learners. In C. Griffiths (Ed.), Lessons from good language learners (pp. 83-98). Cambridge, UK: Cambridge University Press.

Griffiths, C. (2013). The strategy factor in successful language learning. Bristol, UK: Multilingual Matters.

Hauser, R. M. (1994). Measuring socioeconomic status in studies of child development. Child Development, 65, 1541-1545.

Hoff, E. (2006). How social contexts support and shape language development. Developmental Review, 26, 55-88.

Huang, B., Chang, Y-H., Niu, L., \& Zhi, M. (in press). Examining the effects of socio-economic status and language input on adolescent English learners' speech production outcomes. System, https://doi.org/10.1016/j.system.2017.07.004.

Kim, J. S., \& Quinn, D. M. (2013). The effects of summer reading on low-income children's literacy achievement from kindergarten to grade 8: A metaanalysis of classroom and home interventions. Review of Educational Research, 83, 386-431.

Ministry of Health and Welfare, (2017). Retrieved from http://www.mohw.go.kr/eng/index.jsp.

Mueller, C. W., \& Parcel, T. L. (1981). Measures of socioeconomic status: Alternatives and recommendations. Child Development, 52, 13-30.

Nunnally, J. C., \& Bernstein, I. H. (1994). Psychometric theory (3rd ed.). New York, NY: McGraw-Hill.

O'Malley, J. M., Chamot, A., Stewner-Manzanares, G., Kupper, L., \& Russo, R. (1985). Learning strategies used by beginning and intermediate ESL students. Language Learning, 35(1), 21-46.

Oxford, R. L. (1990). Language learning strategies: What every teacher should know. New York, NY: Newbury House.

Oxford, R. L. (2011). Teaching and researching language learning strategies. Harlow, UK: Pearson Longman.

Oxford, R. L., \& Burry-Stock, J. A. (1995). Assessing the use of language learning strategies worldwide with the ESL/EFL version of the Strategy Inventory for Language Learning (SILL). System, 23, 153-175.

Oxford, R. L., \& Nyikos, M. (1989). Variables affecting choice of language learning strategies by university students. The Modern Language Journal, 73(3), $291-300$.

Pawlak, M. (2011). Research into language learning strategies: Taking stock and looking ahead. In J. Arabski, \& A. Wojtaszek (Eds.), Individual learner differences in SLA (pp. 17-37). Bristol, UK: Multilingual Matters.

Pintrich, P., Smith, D., Garcia, T., \& McKeachie, W. (1991). A manual for the use of the motivated strategies for learning questionnaire (MSLQ). Ann Arbor, MI: National Center for Research to Improve Postsecondary Teaching and Learning.

Plonsky, L. (2011). The effectiveness of second language strategy instruction: A meta-analysis. Language Learning, 61, 993-1038.

Raudenbush, S. W., \& Bryk, A. S. (2002). Hierarchical linear models: Applications and data analysis methods (2nd ed.). Thousand Oaks, CA: SAGE.

Reardon, S. F., Valentino, R. A., Kalogrides, D., Shores, K. A., \& Greenberg, E. H. (2013). Patterns and trends in racial academic achievement gaps among states, 1999-2011. Retrieved from https://cepa.stanford.edu/content/patterns-and-trends-racial-academic-achievement-gaps-among-states-1999-2011.

Rubin, J. (1981). Study of cognitive processes in second language learning. Applied Linguistics, 11, 117-131.

Schmidt, R., Boraie, D., \& Kassabgy, O. (1996). Foreign language motivation: Internal structure and external connections. In R. Oxford (Ed.), Language learning motivation: Pathways to the new century (pp. 9-70). Honolulu, HI: University of Hawaii, National Foreign Language Resource Center.

Sirin, S. R. (2005). Socioeconomic status and academic achievement: A meta-analytic review of research. Review of Educational Research, 75, 417-453.

StataCorp. (2015). Stata statistical Software: Release 14. College Station, TX: StataCorp LP.

Stoeber, J., \& Hotham, S. (2013). Perfectionism and social desirability: Students report increased perfectionism to create a positive impression. Personality and Individual Differences, 55, 626-629.

Tenenbaum, H. R., \& Ruck, M. D. (2007). Are teachers' expectations different for racial minority than for European American students? A meta-analysis. Journal of Educational Psychology, 99, 253-273.

Timperley, H. S., \& Phillips, G. (2003). Changing and sustaining teachers' expectations through professional development in literacy. Teaching and Teacher Education, 19, 627-641.

White, K. (1982). The relation between socioeconomic status and academic achievement. Psychological Bulletin, 91, 461-481. 